\title{
"A STUDY ON EFFECTIVENESS OF ONLINE SHOPPING WITH SPECIAL REFERENCE TO CHENNAI CITY"
}

\author{
M. Gokulanathan', Dr. Saraswathy $\mathrm{C}^{2}$ \\ ${ }^{1}$ Research Scholar, Vistas, Pallavaram \\ ${ }^{2}$ Associate Professor, Department Of Commerce, Vistas, Pallavaram
}

\begin{abstract}
Online shopping is current technology has hundreds of purchasing styles and the maximum famous of the times. An digital trade which to take part the shoppers and consumer for directly purchase goods from a dealer over the Internet the use of by a web browser. We come to understand that there are different names given to this such as electronic internet-shop, digital shop, digital store, Internet keep, online store, internet-save, web-store, virtual keep and online storefront, using the cell in application we've, Mobile trade describes purchasing from an internet keep's mobile optimized online website online or applications. There are so many benefits in on line purchasing. An on-line keep arouses the internal analogy of purchasing services or products the manner is called enterprise-to-customer in online shopping. In the case of a business buying from some other business, the procedure is called enterprise-to-business in online buying. The largest of those online retailing businesses are Amazon.Com, flipkart, Alibaba and eBay are all source of online purchasing. The popularity of the advertising and marketing discussion board is important. In this study discussion effectiveness of online shopping and problems are discuss of this study.
\end{abstract}

Keywords:

Online shopping, consumer, Chennai city.

Article Received: 18 October 2020, Revised: 3 November 2020, Accepted: 24 December 2020

\section{INTRODUCTION}

The marketing idea is a philosophy of enterprise. Today, marketing isn't an insignificant physical process of activities concerning the replacing of products. Modern advertising is basically concerned with the introduction of purchasers in different words, identification of the needs of customers after which organizing the commercial enterprise sports to meet the clients' desires. The contemporary commercial enterprise men intention at 'consumers pride' as opposed to customer delight. In fact, modern advertising complements all of the activities worried in identifying the needs of present and capacity customers' for goods and offerings, in purchasing the products from manufacturing Centre and distribution via the transfer of possession. Marketing is in brief supplying what the customers need, when they need, on the vicinity they need, at the price they can come up with the money for and thereby ensuing in the creation of an online purchasers'.

\section{REVIEW OF LITERATURE}

Davis (2018) Consumers' attitudes regarding Internet buying are depending on the direct consequences of relevant online shopping capabilities. Online purchasing functions can be classified into consumer's perceptions of useful and utilitarian dimensions such as "ease of use" and "usefulness", or into their perceptions of emotional and hedonic dimensions like "enjoyment".

Holbrook (1994) Internet customers can be described as 'problem solvers', others can be regarded as searching for 'fun, fantasy, arousal, sensory stimulation, and amusement'. The Problem solvers simply keep online if you want to accumulate a precise product or service, in Which case shopping is considered to be a project' or 'paintings'.

Zinkhan (1998) Claimed that the Internet shifted the stability of electricity in choose of purchasers as it has become very clear for them 
to make buying comparisons and examine options without being forced with the aid of salespeople. Online stores lessen transaction charges and have gained for both customers and vendors. For online shoppers, gender, marital popularity, residential location, age, education, and household income were frequently observed to be critical predictors of online shopping.

\section{AIM OF THE STUDY}

The aim of the study the effectiveness of online shopping, When marketers get to know the factors affecting online consumers buyer's behavior then it create huge opportunity for the marketers to develop the marketing strategies accordingly and turn the potential customers into actual one and retain the exiting buyers.

\subsection{STATEMENT OF THE PROBLEM}

\section{Problems Customers Face While Shopping} Online:

> Product Quality, Logistics are a mess, Delivery Time Is Not Clear, Payment Preferences Are Limited, Payment confirmation missing, The trouble with Hidden costs, Unclear Website Policies.

$>$ The online market is dominated by potential customers both at the domestic and foreign level. There is chance for the customers to lose their interest and their strength being affected because of Consumer towards Online Shopping and the consequential exposure. So, therefore it is necessary to study the problem of the online customers.

\subsection{OBJECTIVES OF THE STUDY}

1. To examine personal factors and frequency of purchase of products towards Online Shopping in Chennai City

2. To find out the problems faced by the consumer towards online shopping.

\subsection{HYPOTHESES OF THE STUDY}

Ho: The relationship between demographic factor and frequency of purchase of products towards
Online Shopping

Ho: The relationship between factors influence and consumers by Online Shopping

\section{RESEARCH METHODOLOGY}

This study is the effectiveness towards Online Shopping analytical and descriptive in nature. It depends upon both primary and secondary data both in analytical and descriptive nature. It deals with the data collected for the study, sources of data, sampling plan the population of the study, location of the research, instrument used to collect data, method of collecting data, analysis and interpretation of the collected data with different statistical tools in order to find out the strength of the collected data and limitations of the study.

\subsection{SAMPLING PLAN}

Since the population of the selected locations for the research is very large and all the respondents could not be interviewed due to practical difficulties, only selected samples have been taken up for the study. Many customers were unwilling to disclose their financial details especially amount of money invested in different purchasing power. Hence the data were collected from the respondents who were willing to disclose the information. Simple random sampling method is used for the study and 175 sampling respondents used in this study but correctly information given by 150 respondents. In order to have illustration from different demographic groups cluster sampling is done to select the respondents.

\subsection{LOCATION OF THE STUDY}

The research adopted simple random sampling method. The respondents chosen from an age group residing in Chennai in age group of $18-75$ years including the different strata of customers like student, teachers, professors, officers, retired salaried class, businessmen, and household customers. 175 questionnaires were distributed to the customers spread over in Chennai city. Among them 175 questionnaires were collected. In which 25 questionnaires were found unusable. Hence, the accurate sample of the study is 150 . 


\subsection{FRAMEWORK ANALYSIS}

This research is based on primary data which were collected from the online customers and factors influencing online shopping through questionnaire. Secondary data is also utilized, which were collected from published source like books, journals, magazines, annual report. The data collected from both the sources is scrutinized, edited and tabulated. The data were analyzed using statistical package for social sciences (IBM-
SPSS-21). The following statistical tools are used in the study. Measures of central tendency and measures of dispersion, One-way analysis of variance, Factor analysis, multiple regression and Chi-square analysis have been employed.

PERSONAL FACTORS AND FREQUENCY OF PURCHASE OF PRODUCTS THROUGH ONLINE

Table 4.1: Chi-square analysis on the relationship between personal factors and frequency of purchase of products in effectiveness of online shopping

\begin{tabular}{|c|l|c|c|c|c|}
\hline S. No & \multicolumn{1}{|c|}{ Study factors } & $\begin{array}{c}\text { Chi-square } \\
\text { value }\end{array}$ & DF & $\begin{array}{c}\text { Significant } \\
\text { Not significant }\end{array}$ & Results \\
\hline 1 & Gender & 8.522 & 2 & 0.202 & NS \\
\hline 2 & Age & 31.063 & 6 & 0.152 & NS \\
\hline 3 & Marital status & 3.224 & 2 & 0.780 & NS \\
\hline 4 & Family members & 33.333 & 8 & 0.097 & NS \\
\hline 5 & Education level & 20.098 & 10 & 0.691 & NS \\
\hline 6 & Occupational status & 32.467 & 10 & 0.116 & NS \\
\hline 7 & Annual income & 19.227 & 8 & 0.740 & NS \\
\hline 8 & Internet access & 15.879 & 6 & 0.601 & NS \\
\hline 9 & Time spent on internet & 35.508 & 8 & 0.041 & NS \\
\hline
\end{tabular}

Significant @1\% level

From the above table 4.1 it is clearly found that they hypothesis is accepted (Not significant) in eight cases and in other cases hypothesis is rejected (Significant). It can be concluded that gender, age, family members, educational level, occupation, annual income and internet access have no influence on the frequency of purchase of products through online mode with other factors and time spent have influence with frequency of purchase of products.

Table 4.2: Kruskal wallis test between age and pre-purchase decisions of the respondents on effectiveness of online shopping

\begin{tabular}{|l|c|c|}
\hline \multicolumn{1}{|c|}{ Age } & $\mathrm{N}$ & Mean Rank \\
\hline \multicolumn{3}{|c|}{ Price of the product } \\
\hline upto 25 years & 21 & 267.11 \\
\hline 25-35 years & 38 & 318.81 \\
\hline 35-45 years & 43 & 322.80 \\
\hline
\end{tabular}

\begin{tabular}{|c|c|c|}
\hline $45-55$ years & 22 & 276.82 \\
\hline $\begin{array}{l}\text { more than } 55 \\
\text { years }\end{array}$ & 26 & 280.95 \\
\hline \multicolumn{3}{|c|}{ Quality of the product } \\
\hline upto 25 years & 21 & 289.46 \\
\hline 25-35 years & 38 & 296.80 \\
\hline $35-45$ years & 43 & 288.38 \\
\hline $45-55$ years & 22 & 324.08 \\
\hline $\begin{array}{l}\text { more than } 55 \\
\text { years }\end{array}$ & 26 & 313.11 \\
\hline \multicolumn{3}{|c|}{$\begin{array}{c}\text { Availability of sufficient product } \\
\text { information }\end{array}$} \\
\hline upto 25 years & 21 & 334.81 \\
\hline 25-35 years & 38 & 302.67 \\
\hline $35-45$ years & 43 & 297.66 \\
\hline $45-55$ years & 22 & 285.64 \\
\hline $\begin{array}{l}\text { more than } 55 \\
\text { years }\end{array}$ & 26 & 285.59 \\
\hline
\end{tabular}




\begin{tabular}{|c|c|c|}
\hline \multicolumn{3}{|c|}{ conditions } \\
\hline upto 25 years & 21 & 380.43 \\
\hline $25-35$ years & 38 & 284.65 \\
\hline $35-45$ years & 43 & 291.71 \\
\hline $45-55$ years & 22 & 291.03 \\
\hline $\begin{array}{l}\text { more than } 55 \\
\text { years }\end{array}$ & 26 & 277.78 \\
\hline \multicolumn{3}{|c|}{ Different choices of payment methods } \\
\hline upto 25 years & 21 & 315.10 \\
\hline $25-35$ years & 38 & 307.93 \\
\hline $35-45$ years & 43 & 285.40 \\
\hline $45-55$ years & 22 & 293.17 \\
\hline $\begin{array}{l}\text { more than } 55 \\
\text { years }\end{array}$ & 26 & 317.90 \\
\hline \multicolumn{3}{|c|}{ Wide range of options } \\
\hline upto 25 years & 21 & 323.56 \\
\hline $25-35$ years & 38 & 335.30 \\
\hline $35-45$ years & 43 & 295.52 \\
\hline $45-55$ years & 22 & 277.13 \\
\hline $\begin{array}{l}\text { more than } 55 \\
\text { years }\end{array}$ & 26 & 237.84 \\
\hline \multicolumn{3}{|c|}{ User-friendly websites } \\
\hline upto 25 years & 21 & 332.28 \\
\hline 25-35 years & 38 & 302.08 \\
\hline $35-45$ years & 43 & 292.72 \\
\hline 45-55 years & 22 & 295.65 \\
\hline $\begin{array}{l}\text { more than } 55 \\
\text { years }\end{array}$ & 26 & 284.92 \\
\hline \multicolumn{3}{|c|}{$\begin{array}{c}\text { Time saving to search product } \\
\text { information }\end{array}$} \\
\hline upto 25 years & 21 & 318.78 \\
\hline 25-35 years & 38 & 293.68 \\
\hline $35-45$ years & 43 & 275.35 \\
\hline
\end{tabular}

\begin{tabular}{|c|c|c|}
\hline $45-55$ years & 22 & 323.91 \\
\hline $\begin{array}{l}\text { more than } 55 \\
\text { years }\end{array}$ & 26 & 318.71 \\
\hline \multicolumn{3}{|c|}{ Attractive discounts } \\
\hline upto 25 years & 21 & 305.99 \\
\hline 25-35 years & 38 & 295.11 \\
\hline $35-45$ years & 43 & 306.44 \\
\hline $45-55$ years & 22 & 285.01 \\
\hline $\begin{array}{lll}\begin{array}{l}\text { more } \\
\text { years }\end{array} & \text { than } 55 \\
\end{array}$ & 26 & 320.63 \\
\hline \multicolumn{3}{|c|}{ User rating and testimonials } \\
\hline upto 25 years & 21 & 329.21 \\
\hline $25-35$ years & 38 & 340.83 \\
\hline $35-45$ years & 43 & 275.16 \\
\hline 45-55 years & 22 & 273.98 \\
\hline $\begin{array}{l}\text { more than } 55 \\
\text { years }\end{array}$ & 26 & 278.72 \\
\hline \multicolumn{3}{|c|}{ Availability of latest items } \\
\hline upto 25 years & 21 & 342.62 \\
\hline $25-35$ years & 38 & 291.07 \\
\hline $35-45$ years & 43 & 296.01 \\
\hline $45-55$ years & 22 & 285.58 \\
\hline $\begin{array}{l}\text { more than } 55 \\
\text { years }\end{array}$ & 26 & 310.14 \\
\hline \multicolumn{3}{|c|}{ Items not available elsewhere } \\
\hline upto 25 years & 21 & 316.52 \\
\hline $25-35$ years & 38 & 331.20 \\
\hline $35-45$ years & 43 & 284.10 \\
\hline 45-55 years & 22 & 282.95 \\
\hline $\begin{array}{l}\text { more than } 55 \\
\text { years }\end{array}$ & 26 & 278.56 \\
\hline
\end{tabular}

Sources: Primary Data

Table 4.2a: Test statistics

\begin{tabular}{|c|c|c|c|c|c|c|c|c|c|c|c|c|}
\hline & Price & $\begin{array}{c}\text { Qualit } \\
\mathrm{y}\end{array}$ & $\begin{array}{c}\text { Availa } \\
\text { bility }\end{array}$ & $\begin{array}{c}\text { Easy } \\
\text { under } \\
\text { standin } \\
\mathrm{g}\end{array}$ & $\begin{array}{c}\text { Choic } \\
\text { es }\end{array}$ & $\begin{array}{l}\text { Wide } \\
\text { range }\end{array}$ & \begin{tabular}{|c} 
User \\
friendl \\
$y$ \\
websit \\
es
\end{tabular} & $\begin{array}{c}\text { Time } \\
\text { savin } \\
\mathrm{g}\end{array}$ & $\begin{array}{c}\text { Disco } \\
\text { unts }\end{array}$ & $\begin{array}{c}\text { Testi } \\
\text { monia } \\
\text { ls }\end{array}$ & $\begin{array}{l}\text { Latest } \\
\text { items }\end{array}$ & \begin{tabular}{|c} 
Not \\
availab \\
le \\
elsewh \\
ere
\end{tabular} \\
\hline $\begin{array}{l}\text { Chi- } \\
\text { Square }\end{array}$ & $\begin{array}{c}12.04 \\
3\end{array}$ & $\begin{array}{c}10.25 \\
0\end{array}$ & 5.199 & 23.193 & 3.799 & 21.68 & $\begin{array}{c}14.43 \\
1\end{array}$ & 8.697 & $\begin{array}{c}12.52 \\
6\end{array}$ & $\begin{array}{c}20.73 \\
8\end{array}$ & $\begin{array}{c}10.81 \\
7\end{array}$ & 10.697 \\
\hline Df & 4 & 4 & 4 & 4 & 4 & 4 & 4 & 4 & 4 & 4 & 4 & 4 \\
\hline $\begin{array}{l}\text { Asymp } \\
\text {. Sig. }\end{array}$ & .017 & .037 & .268 & .000 & .434 & .000 & .011 & .069 & .015 & .000 & .029 & .030 \\
\hline
\end{tabular}


Sources: Primary Date

In above table 4.2 relationship between age and pre-purchase decisions of the respondents has been tested by using Kruskal Wallis test. The highest mean value of 322.80 indicates that respondents from the age group of 35-45 years check price of the product more than other respondents before taking the purchasing decisions. The highest mean value of 324.08 reveals that respondents from the age group of 4555 years check quality of the product more before purchasing. The highest mean score of 334.81 shows that respondents from the age group of upto 25 years check availability of sufficient product information than other respondents. The highest mean value of 380.43 indicates that respondents from the age group of upto 25 years easily understands the terms and conditions about the product before buying it. The highest mean score of 317.90 indicates that respondents from the age group of more than 55 years select different choices of payment methods than other age group of respondents. The highest mean score of 335.30 shows that respondents from the age group of 2535 years seek wide range of options about product before buying. The highest mean value of 332.28 indicates that respondents from the age group of upto 25 years buy products through user-friendly websites more than other respondents. The highest mean score of 323.91 reveal that respondents from the age group of 45-55 years save time more to searching product information than other respondents. The highest mean score of 320.63 reveals that respondents from the age group of more than 55 years expect attractive discounts than other respondents. The highest mean value of 340.83 reveals that respondents from the age group of 25-35 years check user rating and testimonials before buying the product. The highest mean value of 342.62 indicates that respondents from the age group of upto 25 years check availability of latest items than other respondents. The highest mean score of 331.20 shows that respondents from the age group of 2535 years search product items not available elsewhere before buying it respectively. The above table shows that there is significant relationship between age and pre-purchase decisions of the respondents. [Price of the product $=.017<0.05 /$ Quality $=.037<0.05 /$ Availability $=.268>0.05 /$ Easy understanding $=.000<0.05 /$ Different choices $=.434>0.05 /$ Wide range $=$ $.000<0.05 /$ User friendly websites $.011<0.05$ / Time saving to search $=.069>0.05 /$ Attractive discounts $=.015<0.05 /$ User rating $=.000<0.05$ / Availability of latest items $=.029<0.05 /$ Items not available elsewhere $=.030<0.05]$. Hence the calculated value is lower than the table value.

\section{LIMITATIONS OF THE STUDY}

$>\quad$ The study is confined to Chennai city and therefore the conclusion cannot be comprehensive to the entire universe.

$>\quad$ The conclusion may be applicable only to the effectiveness of online shopping towards Chennai city and not for other offline customers.

\section{FINDINGS, SUGGESTIONS}

$>\quad$ As there are not any proper laws for online purchases, they have to be carried out to prevent nameless intruders.

> This will help to hold security and personal facts nicely concerning the respondents. So the internet site developers and service providers should take the necessary steps to triumph over this problem.

> Web-based total technology improvements creative conceptualization that could enhance the reaction from era confidence purchasers. So the companies need to invest in such new technologies. Internet surroundings need to be advanced inside the regions of art, dynamic, and interactive strategies. This development will give more visible appeal. 


\section{CONCLUSION}

The complete manner can variety from some hours to weeks relying on the product, amount, first-class, and source of buy. Today there is an online exchange in the complete state of affairs. Everything in nowadays's international is Internet orientated like Electronic Data Interchange, EMail, E-Business, and E-Commerce. E-Commerce is a change of facts about the usage of community-based technology. In the prevailing excessive price situation, e-Commerce can be used as an aggressive strategy. Privacy of private facts is an enormous problem for a few customers. Many clients want to keep away from unsolicited mail and telemarketing which could end result from presenting contact in-formation to an online merchant. In response, many merchants promise to now not use client statistics for these functions. To grow online purchases, businesses must use sizeable time and money to define, layout, increase, check, implement, and preserve the web store as it is virtually stated that "it's miles easier to lose a purchaser than to advantage one." Even a "top-rated" internet site will no longer be triumphant if the organization fails to exercise common etiquette such as responding to e-mails in a well-timed style, notifying clients of problems, being sincere, and being proper stewards of the clients' information Because it is so critical to dispose of errors and be more attractive to online shoppers, many internets keep designers look at studies on customer expectations.

\section{REFERENCE}

[1] Tulsi Raval, Study of Effectiveness of Online Shopping, Indian journal of applied Research ISSN 2249-555X, Volume 4 Issue 9, pp.76-78 September 2014.

[2] Davis, A Study on Consumer behavior towards online shopping-an empirical study with reference. International journal of advanced research in management 2018

[3] Holbrook (1994) "Web based
Shopping:Consumers' in New

Zealand",Journal of Electronic Commerce Research,Vol. 6,No. 2, ,pp. 80

[4] Guo Jun,Noor Ismawati Jaafar, "A study on consumers satisfaction towards Online Shopping in China",International Journal Of Business and Social Science,Vol. 2 No. 22,Dec 2011,pp. 122-123 